Communication

\title{
Determination of Metals in Tree Rings by ICP-MS Using Ash from a Direct Mercury Analyzer
}

\author{
Byunggwon Jeon and James V. Cizdziel * \\ Department of Chemistry and Biochemistry, University of Mississippi, University, MS 38677, USA; \\ bjeon@go.olemiss.edu \\ * Correspondence: cizdziel@olemiss.edu
}

Academic Editor: Zikri Arslan

Received: 2 April 2020; Accepted: 30 April 2020; Published: 1 May 2020

\begin{abstract}
Elemental profiles in cores of tree trunks (bole wood) have been used for environmental monitoring and reconstruction of metal pollution history. Mercury $(\mathrm{Hg})$ is a global pollutant that can be accurately measured in tree rings in a simple and pragmatic fashion using a direct mercury analyzer (DMA) that is based on thermal decomposition, amalgamation, and atomic absorption spectrophotometry. In this feasibility study, we demonstrate that the ash remaining after the DMA analyses can be used to quantify a wide range of other non-volatile elements $(\mathrm{Ba}, \mathrm{Be}, \mathrm{Co}, \mathrm{Cr}, \mathrm{Cu}, \mathrm{Fe}$, $\mathrm{Ga}, \mathrm{Mg}, \mathrm{Mn}, \mathrm{Ni}, \mathrm{Pb}, \mathrm{Sr}$, Th, and $\mathrm{U}$ ) in that same sample of wood by inductively coupled plasma mass spectrometry (ICP-MS) after microwave-assisted acid digestion. Other elements ( $\mathrm{Ag}, \mathrm{Cd}, \mathrm{Cs}, \mathrm{Rb}, \mathrm{Tl}$, and $\mathrm{V}$ ) exhibited poor recoveries, possibly due to losses during sample preparation. We assessed the accuracy with reference materials, spikes, and by comparison with EPA Method 3052 (Microwave Assisted Acid Digestion of Siliceous and Organically Based Matrices). For the first group of elements (deemed suitable for the method), recoveries ranged between $80 \%$ and $120 \%$ and the relative standard deviation was generally $<15 \%$, indicating acceptable precision. We applied the method to five species of trees: eastern red cedar (Juniperus virginiana), loblolly pine (Pinus taeda), shortleaf pine (Pinus echinata), white oak (Quercus alba), and tulip poplar (Liriodendron tulipifera) from Holly Springs National Forest in north Mississippi, USA. Mercury concentrations (ng/g \pm SE) were highest in the cedar $(1.8 \pm 0.3 ; n=5)$, followed by loblolly pine $(1.6 \pm 0.3, n=3)$, shortleaf pine $(1.2 \pm 0.2 ; n=3)$, oak $(1.1 \pm 0.2 ; n=5)$, and poplar $(0.5 \pm 0.1 ; n=5)$. Concentrations of other elements were generally $\mathrm{Fe}>\mathrm{Mg}>\mathrm{Ba} \approx \mathrm{Sr} \approx \mathrm{Mn}>\mathrm{Cr} \approx \mathrm{Cu}>\mathrm{Ni} \approx \mathrm{Rb}>\mathrm{Co}>\mathrm{Ga} \approx \mathrm{Ag}$, with the other elements generally below the method detection limit (MDL). Overall, we showed that the DMA can be used to not only determine total $\mathrm{Hg}$ in segments of tree core, but can serve as the ashing step in the preparation of wood for ICP-MS analysis, thus allowing the determination of non-volatile elements along with $\mathrm{Hg}$ in the very same sample.
\end{abstract}

Keywords: mercury pollution; tree rings; trace elements; ashing; national forest; direct mercury analyzer; ICP-MS

\section{Introduction}

Profiles of trace elements, including $\mathrm{Hg}$ and other toxic metals, in tree rings have been used in a variety of studies worldwide for environmental monitoring and the reconstruction of pollution history [1-4]. These dendrochemical investigations rely on the preservation of a chemical record of metal deposition from the local environment incorporated into the annual growth increments of trees [5]. In some cases, when there are overlapping features from living and dead trees that have preserved timber, annually resolved chronologies can stretch back hundreds of years [6]. However, using tree rings as records of environmental pollution requires caution due to potential differences in both the mobility of elements in wood and in physiological mechanisms of uptake of elements among species [7]. 
Whereas analysis of an individual tree-ring may not pinpoint a specific year of environmental change, trees can record long-term patterns and serve as biomonitors of macro-environmental trends [8]. Thus, there continues to be interest in rapid and pragmatic analytical methods for dendroanalysis, especially for methods capable of determining multiple elements, including $\mathrm{Hg}$.

Mercury is a global pollutant transported through the atmosphere that is incorporated into tree tissues primarily through atmospheric deposition $[4,9,10]$. Monitoring $\mathrm{Hg}$ in the environment is essential for evaluating the effectiveness of the recent (2017) Minamata convention, a global regulatory mechanism to decrease environmental Hg loadings [11]. While some studies have shown that tree cores can serve as temporal total-Hg biomonitors, recording changes in $\mathrm{Hg}$ deposition with pollution history [4,10,12], others have not [13], suggesting that the cycling of $\mathrm{Hg}$ in individual species of trees needs to be further investigated. In any case, quantifying $\mathrm{Hg}$ in tree wood and other tissues is also important to understanding the pools and fluxes of $\mathrm{Hg}$ in forest ecosystems [10]. However, measuring $\mathrm{Hg}$ in trees, especially wood, is difficult due to its low concentration, which is often below method detection limits [14]. Despite its low concentration, the Hg content of wood often comprises the largest pool of $\mathrm{Hg}$ in forests, except for the soil, due to its relatively high biomass [15]. Moreover, wildfires are a poorly characterized but potentially important source of $\mathrm{Hg}$ to the atmosphere, and a lack of data on $\mathrm{Hg}$ in wood is leading to uncertainty in ecosystem $\mathrm{Hg}$ budgets [10,14].

Recently, Yang et al. [14] showed that a direct mercury analyzer (DMA), based on thermal decomposition, catalytic conversion, amalgamation, and atomic absorption spectrophotometry, can reliably measure $\mathrm{Hg}$ in wood. The method is popular because compared to inductively coupled plasma mass spectrometry (ICP-MS), it is much less costly, requires virtually no sample preparation, is rapid ( $<6 \mathrm{~min} / \mathrm{sample}$ ), and can be run by students after minimal training. Moreover, whereas $\mathrm{Hg}$ can be effectively determined by ICP-MS, the analyst must be keenly aware of a number of pitfalls, including potential carryover as $\mathrm{Hg}$ is prone to "memory" effects (e.g., sorption/desorption from pump tubing). Mercury also has a relatively high ionization potential $(\sim 10.4 \mathrm{eV})$ and its signal is spread out over its seven stable isotopes. Thus, $\mathrm{Hg}$ in bole wood is increasingly being determined with DMAs. However, the ash that remains after the $\mathrm{Hg}$ analysis is typically discarded, despite containing non-volatile elements whose concentration can also be determined for pollution and other dendrochemistry-related studies.

The purpose of the current study was to develop and validate an analytical method for the analysis of bole wood tree rings which combines the determination of total-Hg using the DMA with multi-elemental analysis using ICP-MS. Effectively, we used the DMA as a sample-ashing step before microwave-assisted acid digestion and ICP-MS analysis of the diluted bole wood digests. As we have not seen this approach documented in the scientific literature, and because others are now routinely measuring $\mathrm{Hg}$ in tree wood using DMAs as it has becomes apparent that wood is, by mass, the most important reservoir of $\mathrm{Hg}$ in forests after soil [16,17], we carefully evaluate and optimize the method. Here, we report on the methodology and its application to trees from Holly Springs National Forest in Mississippi, which will serve as a background site for future dendrochemical studies tracing the pollution history of coal-fired power plants and other potential point sources of airborne metal pollution in the region. We focused on the outer (most recent) tree rings; fully quantifying the distribution and trends of $\mathrm{Hg}$ and other elements in the full tree cores is beyond the scope of this method feasibility study.

\section{Results and Discussion}

\subsection{Method Comparison, Figures-of-Merit, and Recovery Tests}

EPA method 3052 is a common microwave digestion method applicable to organic matrices that uses $9 \mathrm{~mL}$ of concentrated $\mathrm{HNO}_{3}$ and $3 \mathrm{~mL}$ of concentrated HF. However, given our sample size $(\sim 0.1$ $\mathrm{g}$ ) and the low concentration of many elements in wood, we modified the method to reduce dilution while maintaining optimal digestion conditions. To compare our DMA-ICPMS method to the EPA 
method, we prepared a homogenized mixture of pulverized bole wood from white oak (Quercus alba) by cryogenic grinding (Spex 6875 Freezer/Mill) of the wood from multiple tree cores. The material was analyzed directly by EPA method 3052 and by our method after ashing with a DMA. Our method, described later, uses three "micro-inserts" in each digestion vessel and only $1.5 \mathrm{~mL} \mathrm{HNO}_{3}$ and $50 \mu \mathrm{L}$ of HF. The results show good agreement between the two approaches, except for Cd, Cs, and $\mathrm{Tl}$ (Table 1). Cadmium is known to be volatile and is likely lost during the DMA analyses; Cs can form a metal oxide that can attack silica, and Tl was near the MDL (Table 1).

Table 1. Comparison of the new method (with DMA ashing) with a standard method (EPA 3052, without DMA ashing) for determination of metals in pulverized bole wood prepared by cryogenic milling. Figures-of-merit are for the new method. Starred values indicate a relative percent difference (RPD) exceeding $25 \%$, suggesting that the element may not be suitable for this method.

\begin{tabular}{|c|c|c|c|c|c|c|}
\hline \multirow{2}{*}{ Element } & \multicolumn{2}{|c|}{ Mean ( $\pm 1 \mathrm{SD} ; n=5)$} & \multirow{2}{*}{ RPD } & \multirow{2}{*}{ MDL } & \multirow{2}{*}{ LOQ } & \multirow{2}{*}{$\begin{array}{l}\text { Calib. Curve } \\
\text { Linearity }\left(r^{2}\right)\end{array}$} \\
\hline & EPA 3052 & New Method & & & & \\
\hline Ag (ng/g) & $11.5 \pm 6.9$ & $<\mathrm{MDL}$ & - & 5.1 & 17.2 & 0.9995 \\
\hline $\mathrm{Ba}(\mu \mathrm{g} / \mathrm{g})$ & $200 \pm 8$ & $192 \pm 4$ & 4.1 & 0.04 & 0.12 & 0.9990 \\
\hline Be (ng/g) & $80 \pm 10$ & $82 \pm 18$ & 3.1 & 15.2 & 50.7 & 0.9996 \\
\hline $\mathrm{Cd}(\mathrm{ng} / \mathrm{g})$ & $250 \pm 8$ & $67 \pm 12$ & $73.3 *$ & 7.2 & 23.9 & 0.9999 \\
\hline Co (ng/g) & $348 \pm 24$ & $353 \pm 47$ & 1.4 & 1.5 & 4.9 & 0.9999 \\
\hline $\mathrm{Cr}(\mu \mathrm{g} / \mathrm{g})$ & $34.5 \pm 4.4$ & $31.0 \pm 1.5$ & 10.4 & 0.05 & 0.18 & 0.9999 \\
\hline Cs (ng/g) & $6.0 \pm 0.3$ & $10.1 \pm 4.4$ & $67.2 *$ & 2.1 & 7.1 & 0.9993 \\
\hline $\mathrm{Cu}(\mu \mathrm{g} / \mathrm{g})$ & $1.9 \pm 1.0$ & $1.7 \pm 1.3$ & 14.2 & 1.1 & 3.7 & 0.9999 \\
\hline $\mathrm{Fe}(\mu \mathrm{g} / \mathrm{g})$ & $156 \pm 20$ & $188 \pm 56$ & 20.8 & 0.81 & 2.72 & 0.9961 \\
\hline $\mathrm{Ga}(\mathrm{ng} / \mathrm{g})$ & $7.0 \pm 2.5$ & $8.6 \pm 4.4$ & 23.5 & 1.3 & 4.5 & 0.9999 \\
\hline $\mathrm{Mg}(\mu \mathrm{g} / \mathrm{g})$ & $1200 \pm 48$ & $1200 \pm 71$ & 1.6 & 1.2 & 3.9 & 0.9947 \\
\hline $\mathrm{Mn}(\mu \mathrm{g} / \mathrm{g})$ & $100.0 \pm 4.6$ & $96.3 \pm 0.9$ & 3.7 & 0.10 & 0.34 & 0.9986 \\
\hline $\mathrm{Ni}(\mu \mathrm{g} / \mathrm{g})$ & $13.4 \pm 1.6$ & $13.2 \pm 0.5$ & 1.4 & 0.05 & 0.17 & 0.9999 \\
\hline $\mathrm{Pb}(\mu \mathrm{g} / \mathrm{g})$ & $1.71 \pm 0.07$ & $1.72 \pm 0.06$ & 0.9 & 0.06 & 0.19 & 0.9998 \\
\hline $\mathrm{Rb}(\mu \mathrm{g} / \mathrm{g})$ & $4.52 \pm 0.17$ & $4.30 \pm 0.06$ & 4.8 & 0.02 & 0.08 & 0.9999 \\
\hline $\mathrm{Sr}(\mu \mathrm{g} / \mathrm{g})$ & $49.5 \pm 2.1$ & $47.0 \pm 0.3$ & 5.2 & 0.02 & 0.07 & 0.9999 \\
\hline Th (ng/g) & $3.2 \pm 4.3$ & $<$ MDL & - & 2.4 & 7.9 & 0.9994 \\
\hline $\mathrm{Tl}$ (ng/g) & $4.7 \pm 0.5$ & $3.0 \pm 0.7$ & $36.4 *$ & 2.9 & 9.8 & 0.9994 \\
\hline U (ng/g) & $4.4 \pm 2.3$ & $3.6 \pm 1.5$ & 19.5 & 1.7 & 5.6 & 0.9986 \\
\hline V (ng/g) & $210 \pm 30$ & $220 \pm 20$ & 0.9 & 3.2 & 10.5 & 0.9999 \\
\hline
\end{tabular}

Note: Method detection limit (MDL) and limit of quantitation (LOQ) are based on a $0.1 \mathrm{~g}$ sample of wood.

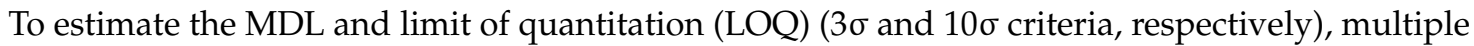
reagent blanks were included with each set of digestions. MDLs ranged from $<5 \mathrm{ng} / \mathrm{g}$ for $\mathrm{Ag}, \mathrm{Co}, \mathrm{Cs}$, $\mathrm{Ga}, \mathrm{Th}, \mathrm{Tl}, \mathrm{U}, \mathrm{V}$ to $1.2 \mu \mathrm{g} / \mathrm{g}$ for $\mathrm{Mg}$ (Table 1 ). All calibration curves were $>0.994$. For those elements suitable for the method, the relative standard deviation for the reference material was generally $<15 \%$, indicating acceptable precision.

To check the accuracy of the method, we also analyzed reference materials, including CRM AR 1946 (wood fuel biomass) and NIST SRM 1633C (coal fly ash), the latter with and without DMA analysis (ashing). In addition, because only three of the twenty elements determined were certified in the wood reference material (six others had reference values), we spiked the wood CRM with $10 \mu \mathrm{L}$ of a $10 \mu \mathrm{g} / \mathrm{mL}$ multi-element standard (to yield $\sim 0.4 \mathrm{ng} / \mathrm{g}$ in the final diluted solution) and analyzed the material both with and without DMA ashing using microwave digestion and ICP-MS. The results for these recovery tests are summarized in Table 2. Recoveries for the three certified elements, $\mathrm{Mg}, \mathrm{Fe}$, and $\mathrm{Mn}$, in the wood reference material were 93\%, 99\%, and 110\%, respectively. Recoveries for Sr (97\%), Ba (117\%), and $\mathrm{Cu}(118 \%)$ were also acceptable. Recoveries for $\mathrm{Ni}, \mathrm{Pb}$, and $\mathrm{V}$ were low (31\% to 51\%); however, these elements only had reference values and $\mathrm{Ni}$ and $\mathrm{Pb}$ performed much better with spikes of the wood CRM as well as the other reference material where their concentration was certified. Recoveries for $\mathrm{V}$ were mixed with some low values $\sim 60 \%$; thus, the element should be carefully monitored as it may not be suited for this method. 
Table 2. Recoveries for reference materials determined by ICP-MS after microwave digestion with or without prior ashing by a direct mercury analyzer.

\begin{tabular}{|c|c|c|c|c|c|c|c|c|c|c|c|c|c|c|c|c|c|}
\hline \multirow{3}{*}{ Element (Unit) } & \multicolumn{5}{|c|}{ CRM AR 1946 (Wood Fuel Biomass) } & \multicolumn{8}{|c|}{ NIST SRM 1633C (Coal Fly Ash) } & \multicolumn{4}{|c|}{$\begin{array}{c}\text { AR1946 Spiked with } \\
\text { Multi-element Standard }\end{array}$} \\
\hline & \multicolumn{2}{|c|}{$\begin{array}{c}\text { Certified or } \\
\text { Reference Value }\end{array}$} & \multicolumn{3}{|c|}{$\begin{array}{c}\text { With DMA } \\
\text { Ashing }(n=3)\end{array}$} & \multicolumn{2}{|c|}{$\begin{array}{l}\text { Certified or Reference } \\
\text { Value }\end{array}$} & \multicolumn{3}{|c|}{$\begin{array}{c}\text { With DMA } \\
\text { Ashing }(n=8)\end{array}$} & \multicolumn{3}{|c|}{$\begin{array}{l}\text { Without DMA } \\
\text { Ashing }(n=8)\end{array}$} & \multicolumn{2}{|c|}{$\begin{array}{c}\text { With DMA } \\
\text { Ashing }(n=2)\end{array}$} & \multicolumn{2}{|c|}{$\begin{array}{l}\text { Without DMA } \\
\text { Ashing }(n=3)\end{array}$} \\
\hline & Mean & $1 \mathrm{SD}$ & Mean & $1 \mathrm{SD}$ & $\begin{array}{l}\text { Rec. } \\
(\%)\end{array}$ & Mean & $1 \mathrm{SD}$ & Mean & $1 \mathrm{SD}$ & $\begin{array}{l}\text { Rec. } \\
(\%)\end{array}$ & Mean & $1 \mathrm{SD}$ & $\begin{array}{l}\text { Rec. } \\
(\%)\end{array}$ & $\begin{array}{l}\text { Rec. } \\
(\%)\end{array}$ & RPD & $\begin{array}{l}\text { Rec. } \\
(\%)\end{array}$ & SD \\
\hline Ag (ng/g) & - & - & 14.0 & 6.0 & - & - & - & $<\mathrm{MDL}$ & 0.1 & - & $<\mathrm{MDL}$ & 0.0 & - & 96.3 & 10.6 & 123.4 & 7.4 \\
\hline $\mathrm{Ba}(\mu \mathrm{g} / \mathrm{g})$ & 47 (ref) & - & 54.9 & 2.0 & 116.8 & 1126 & 33 & 1158 & 83.6 & 102.9 & 1243 & 70.3 & 110.4 & 96.8 & 5.7 & 91.9 & 11.8 \\
\hline Be (ng/g) & - & - & $<$ MDL & 4.0 & - & - & - & $<\mathrm{MDL}$ & - & - & $<\mathrm{MDL}$ & - & - & 86.6 & 12.1 & 114.5 & 7.5 \\
\hline $\mathrm{Cd}$ (ng/g) & - & - & 39.0 & 11.0 & - & 0.758 & 0.005 & $<\mathrm{MDL}$ & - & 156.4 & $<\mathrm{MDL}$ & - & 140.7 & 7.6 & 110.4 & 110.0 & 7.7 \\
\hline Co $(\mu \mathrm{g} / \mathrm{g})$ & - & - & $<\mathrm{MDL}$ & 0.1 & - & 42.9 & 3.5 & 36.8 & 3.4 & 85.9 & 37.8 & 0.8 & 88.0 & 76.0 & 16.8 & 103.7 & 11.7 \\
\hline $\mathrm{Cr}(\mu \mathrm{g} / \mathrm{g})$ & - & - & 2.2 & 0.2 & - & 258 (ref) & 6 & 207 & 18 & 80.2 & 217.8 & 2.1 & 84.4 & 98.2 & 4.9 & 123.0 & 18.1 \\
\hline Cs (ng/g) & - & - & 35.0 & 6.0 & - & 9.39 (ref) & 0.22 & 4.7 & 1.2 & 50.0 & 8.0 & 0.2 & 85.2 & 76.9 & 7.4 & 114.1 & 8.1 \\
\hline $\mathrm{Cu}(\mu \mathrm{g} / \mathrm{g})$ & 4 (ref) & - & 4.7 & 3.0 & 118.3 & 173.7 & 6.4 & 154.8 & 12.0 & 89.1 & 159.3 & 3.4 & 91.7 & - & - & 100.1 & 14.9 \\
\hline $\mathrm{Fe}(\%)$ & 0.110 & 0.020 & 0.109 & 0.012 & 99.4 & 10.49 & 0.39 & 1.48 & 0.12 & 14.1 & 1.51 & 0.04 & 14.4 & 86.6 & 0.3 & 85.6 & 9.1 \\
\hline Ga (ng/g) & - & - & 112.0 & 3.0 & - & - & - & 47.6 & 4.1 & - & 48.5 & 1.1 & - & 87.8 & 12.6 & 110.4 & 9.7 \\
\hline $\mathrm{Mg}(\mu \mathrm{g} / \mathrm{g})$ & 480 & 10.0 & 445 & 8.6 & 92.7 & 4980 & 520 & 278 & 81.5 & 14.0 & 637.5 & 26.4 & 32.2 & 93.0 & 6.4 & 87.4 & 14.8 \\
\hline $\mathrm{Mn}(\mu \mathrm{g} / \mathrm{g})$ & 110 & 10.0 & 121 & 3.7 & 109.8 & 240.2 & 3.4 & 204 & 21.7 & 84.8 & 207.7 & 3.5 & 86.5 & 94.2 & 8.2 & 90.0 & 14.1 \\
\hline $\mathrm{Ni}(\mu \mathrm{g} / \mathrm{g})$ & 3 (ref) & - & 1.3 & 0.2 & 43.5 & 132.0 & 10.0 & 129 & 21.6 & 97.6 & 124.6 & 2.5 & 94.4 & 80.6 & 39.2 & 111.2 & 7.1 \\
\hline $\mathrm{Pb}(\mu \mathrm{g} / \mathrm{g})$ & 4 (ref) & - & 1.2 & 0.3 & 31.1 & 95.2 & 2.5 & 95.1 & 5.3 & 100.1 & 91.0 & 1.4 & 95.6 & 97.4 & 100.2 & 111.1 & 0.8 \\
\hline $\mathrm{Rb}(\mu \mathrm{g} / \mathrm{g})$ & - & - & 2.9 & 0.0 & - & 117.42 & 0.53 & 31.2 & 2.2 & 26.6 & 43.8 & 2.4 & 37.3 & 56.4 & 68.3 & 95.7 & 15.6 \\
\hline $\mathrm{Sr}(\mu \mathrm{g} / \mathrm{g})$ & 33 (ref) & - & 32.1 & 0.4 & 97.2 & 901 & 56 & 730 & 65 & 81.0 & 858.2 & 10.8 & 95.3 & 97.5 & 9.5 & 96.7 & 7.1 \\
\hline Th (ng/g) & - & - & 82.0 & 13.0 & - & 23.0 (ref) & 0.4 & $<\mathrm{MDL}$ & - & 7.4 & 3.8 & 0.1 & 16.5 & 83.9 & 9.8 & 109.1 & 18.8 \\
\hline $\mathrm{Tl}$ (ng/g) & - & - & $<\mathrm{MDL}$ & 0.0 & - & - & - & 5.9 & 0.5 & - & 5.7 & 0.1 & - & 52.9 & 16.4 & 114.9 & 7.3 \\
\hline $\mathrm{U}(\mathrm{ng} / \mathrm{g})$ & - & - & 30.0 & 7.0 & - & 9.25 (ref) & 0.45 & 8.4 & 0.6 & 90.8 & 8.0 & 0.1 & 86.5 & 85.1 & 13.8 & 117.0 & 8.3 \\
\hline V(ng/g) & 3 (ref) & - & 1.7 & 0.2 & 58.0 & 286.2 & 7.9 & 247 & 19 & 86.3 & 256.3 & 4.2 & 89.5 & 61.1 & 21.1 & 105.0 & 0.4 \\
\hline
\end{tabular}

Note: Dashes (-) = not available; RPD = relative percent difference. 
Recoveries for the coal fly ash ranged from $80 \%$ to $110 \%$ for $\mathrm{Ba}, \mathrm{Co}, \mathrm{Cr}, \mathrm{Cu}, \mathrm{Mn}, \mathrm{Ni}, \mathrm{Pb}, \mathrm{Sr}, \mathrm{U}, \mathrm{V}$ for both DMA-heated samples and samples that were analyzed directly without the DMA. Recoveries for $\mathrm{Cd}, \mathrm{Cs}, \mathrm{Tl}$ were poor, as was the case in our comparison with the EPA method (above), suggesting that these elements are also not well-suited for this method. Recoveries from the coal fly ash were also poor for $\mathrm{Fe}, \mathrm{Mg}$, Th, and $\mathrm{Rb}$, but that was the case for both DMA and non-DMA samples and given good recoveries from the wood reference material (both with and without DMA-ashing), the effect is likely matrix-dependent and coal fly ash is substantially different from wood ash. Thus, we feel that the method is suitable to determine $\mathrm{Fe}, \mathrm{Mg}$, Th and $\mathrm{Rb}$ in tree cores.

In summary, $\mathrm{Ag}, \mathrm{Cd}, \mathrm{Cs}, \mathrm{Rb}, \mathrm{Tl}$, and $\mathrm{V}$ are problematic and probably should not be quantified using this method; the remaining elements $\mathrm{Ba}, \mathrm{Be}, \mathrm{Co}, \mathrm{Cr}, \mathrm{Cu}, \mathrm{Fe}, \mathrm{Ga}, \mathrm{Hg}, \mathrm{Mg}, \mathrm{Mn}, \mathrm{Ni}, \mathrm{Pb}, \mathrm{Sr}, \mathrm{Th}$, and $\mathrm{U})$ can be quantified if the concentration is above the MDL in the tree wood. In any case, we emphasize that it is important that each laboratory documents the reliability of their own data using appropriate quality assurance measures.

\subsection{Analysis of Tree Cores Collected from the Holly Springs National Forest}

We applied the method to bole wood collected from five tree species in Holly Springs National Forest. Mercury concentrations (ng/g $\pm 1 \mathrm{SE}$ ) were highest in the cedar $(1.8 \pm 0.3 ; n=5)$, followed by loblolly pine $(1.6 \pm 0.3, n=3)$, shortleaf pine $(1.2 \pm 0.3 ; n=3)$, white oak $(1.1 \pm 0.2 ; n=5)$, and tulip poplar $(0.5 \pm 0.1, n=5)$ (Figure 1$)$. These concentrations are similar with those reported in other studies of tree cores: for example, $\mathrm{Hg}$ concentrations in cores deciduous trees cores from Ontario, Canada, including poplar (Populus deltoids), willow (Salix x rubens), and red oak (Quercus rubra) ranged from $\sim 0.7$ to $4.1 \mathrm{ng} / \mathrm{g}$ [13], and in hardwoods and conifers from the northeast USA, American beech (Fagus Grandifolia), yellow birch (Betula Alleghaniensis), red maple (Acer Rubrum), sugar maple (Acer Saccharum), red spruce (Picea Rubens), white ash (Fraxinus Americana), white pine (Pinus Strobus) and balsam fir (Abies Balsamea) ranged from $\sim 0.4$ to $5 \mathrm{ng} / \mathrm{g}[10,13]$. It is important to note that recent work has shown the suitability of tree rings as archives of global and regional atmospheric Hg pollution [18], and has been used track atmospheric Hg pollution, including from past mining operations in Australia [19].

\section{5}

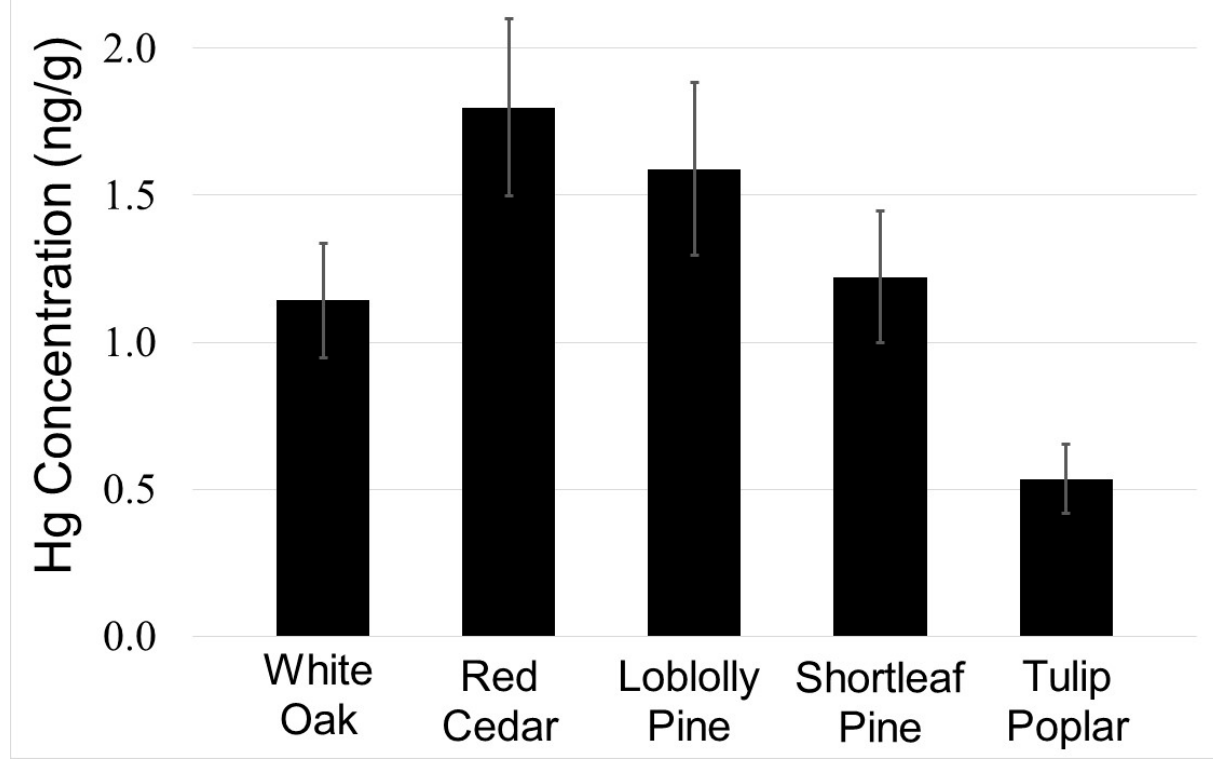

Figure 1. Mean mercury concentration in tree rings from the Tallahatchie Experimental Forest in Holly Springs National Forest in north Mississippi determined with a direct mercury analyzer. Error bars are \pm 1 standard error. 
Concentrations of elements determined in the DMA-ash by ICP-MS were generally in the following order, $\mathrm{Fe}>\mathrm{Mg}>\mathrm{Ba} \approx \mathrm{Sr} \approx \mathrm{Mn}>\mathrm{Cr} \approx \mathrm{Cu}>\mathrm{Ni}>\mathrm{Co}>\mathrm{Pb}$, with several other elements (Be, Th, $\mathrm{Ga}$, $\mathrm{U})$ routinely near or below the MDL regardless of species (Figure 2, Table 3). In general, elemental concentrations were higher in the slow-growing oak and cedar, compared to the pine and tulip poplar. Most of the trace metal concentrations are comparable to measurements of tree rings from other studies conducted in relatively pristine areas, and lower than those from contaminated areas. Cocozza et al. [20] measured relatively high concentrations of $\mathrm{Co}(>50 \mu \mathrm{g} / \mathrm{g})$ in tree rings collected from downy oak (Quercus Pubescens) near an incinerator in an industrial area. Our highest measurement of Co was $0.41 \mu \mathrm{g} / \mathrm{g}$. In another study, Madejón et al. [21] measured $63 \mu \mathrm{g} / \mathrm{g}$ of Pb in white poplar (Populus $A l b a)$ in riparian forests contaminated from a mine waste spill. All but one of our measurements for $\mathrm{Pb}$ were $<1 \mu \mathrm{g} / \mathrm{g}$.
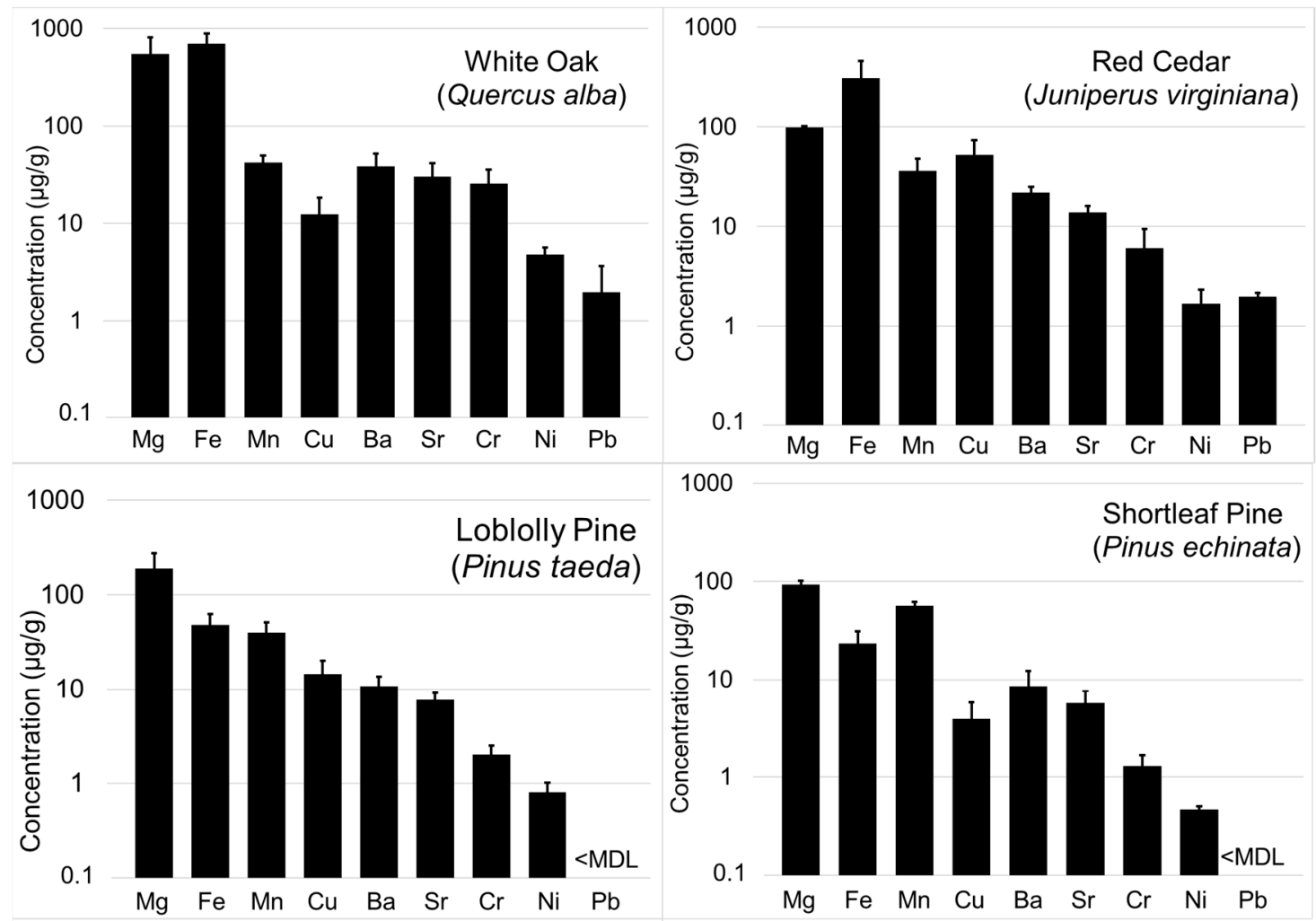

1000

Tulip Poplar

(Liriodendron tulipifera)

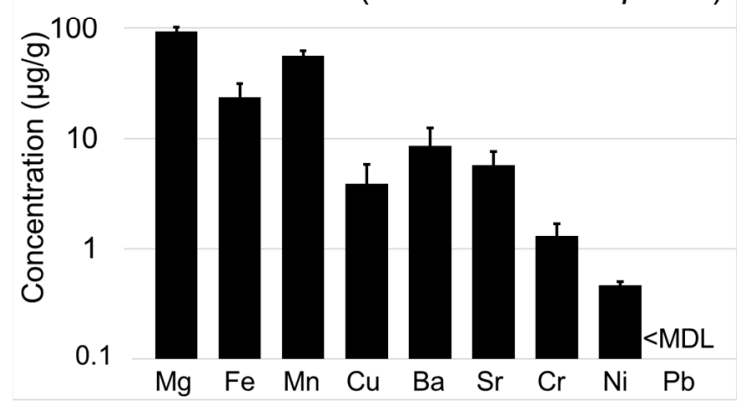

Figure 2. Mean concentrations of elements in bole wood tree rings from the Tallahatchie Experimental Forest in Holly Springs National Forest in north Mississippi determined by ICP-MS using ash from a direct mercury analyzer. Note: $y$-axis is on a logarithmic scale and error bars are \pm 1 standard error. 
Table 3. Concentration of elements in tree cores from the Tallahatchie Experimental Forest in Holly Springs National Forest in north Mississippi determined by ICP-MS using ash from a direct mercury analyzer.

\begin{tabular}{|c|c|c|c|c|c|c|c|c|c|c|c|c|c|c|c|}
\hline \multirow[t]{2}{*}{ Species: } & \multicolumn{3}{|c|}{ Quercus Alba } & \multicolumn{3}{|c|}{ Juniperus Virginiana } & \multicolumn{3}{|c|}{ Pinus Taeda } & \multicolumn{3}{|c|}{ Pinus Echinata } & \multicolumn{3}{|c|}{ Liriodendron Tulipifera } \\
\hline & Tree 1 & Tree 2 & Tree 3 & Tree 1 & Tree 2 & Tree 3 & Tree 1 & Tree 2 & Tree 3 & Tree 1 & Tree 2 & Tree 3 & Tree 1 & Tree 2 & Tree 3 \\
\hline $\begin{array}{c}\text { Circumference } \\
(\mathrm{cm}) \text { : }\end{array}$ & 137 & 129 & 80 & 57 & 48 & 47 & 32 & 88 & 153 & 88 & 109 & 83 & 151 & 109 & 160 \\
\hline $\begin{array}{l}\mathrm{Ag}(\mathrm{ng} / \mathrm{g}) \\
\mathrm{Ba}(\mu \mathrm{g} / \mathrm{g})\end{array}$ & $\begin{array}{c}<\mathrm{MDL} \\
26.4\end{array}$ & $\begin{array}{c}<\mathrm{MDL} \\
66.4\end{array}$ & $\begin{array}{c}<\mathrm{MDL} \\
23.2\end{array}$ & $\begin{array}{l}13.1 \\
27.4\end{array}$ & $\begin{array}{l}20.9 \\
21.9\end{array}$ & $\begin{array}{c}<\mathrm{MDL} \\
17.1\end{array}$ & $\begin{array}{c}<\mathrm{MDL} \\
16.2\end{array}$ & $\begin{array}{c}<\mathrm{MDL} \\
9.0\end{array}$ & $\begin{array}{c}<\mathrm{MDL} \\
7.0\end{array}$ & $\begin{array}{c}- \\
6.5\end{array}$ & $\begin{array}{c}<\mathrm{MDL} \\
15.9\end{array}$ & $\begin{array}{c}<\mathrm{MDL} \\
3.2\end{array}$ & $\begin{array}{c}<\mathrm{MDL} \\
19.1\end{array}$ & $\begin{array}{c}<\mathrm{MDL} \\
49.4\end{array}$ & $\begin{array}{c}<\mathrm{MDL} \\
29.3\end{array}$ \\
\hline $\mathrm{Be}(\mathrm{ng} / \mathrm{g})$ & $<\mathrm{MDL}$ & 41.3 & $<\mathrm{MDL}$ & $<\mathrm{MDL}$ & $<\mathrm{MDL}$ & $<$ MDL & $<\mathrm{MDL}$ & $<\mathrm{MDL}$ & $<\mathrm{MDL}$ & $<\mathrm{MDL}$ & $<\mathrm{MDL}$ & $<$ MDL & $<\mathrm{MDL}$ & $<\mathrm{MDL}$ & $<\mathrm{MDL}$ \\
\hline Co (ng/g) & 196 & 414 & 237 & 93.9 & 48.9 & 141 & 62.7 & 58.1 & 20.5 & 32.2 & 35.6 & 15.4 & 42.5 & - & 89.8 \\
\hline $\mathrm{Cr}(\mu \mathrm{g} / \mathrm{g})$ & 22.7 & 10.6 & 44.1 & 4.8 & 1.1 & 12.5 & 1.6 & 3.0 & 1.4 & 1.2 & 2.0 & 0.7 & 1.6 & 3.3 & 3.5 \\
\hline $\mathrm{Cu}(\mu \mathrm{g} / \mathrm{g})$ & 2.3 & 12.6 & 22.5 & 83.4 & 62.2 & 13.2 & 25.1 & 12.7 & 5.4 & 2.3 & 7.7 & 1.7 & 3.0 & 6.1 & 7.1 \\
\hline $\mathrm{Fe}(\mu \mathrm{g} / \mathrm{g})$ & 687 & 373 & 1041 & 321 & 33.8 & 567 & 48.7 & 72.1 & 24.1 & 20.3 & 38.0 & 12.3 & 22.4 & 76.7 & 71.1 \\
\hline $\mathrm{Ga}(\mathrm{ng} / \mathrm{g})$ & 36.0 & 22.7 & 19.8 & 37.2 & 37.4 & 43.3 & 42.9 & $<\mathrm{MDL}$ & $<\mathrm{MDL}$ & $<\mathrm{MDL}$ & $<\mathrm{MDL}$ & 0.3 & 0.1 & 1.6 & 2.5 \\
\hline $\mathrm{Hg}(\mathrm{ng} / \mathrm{g}) *$ & 1.0 & 1.1 & 0.9 & 2.1 & 2.0 & 1.9 & 2.2 & 1.4 & 1.2 & 1.4 & 1.5 & 0.8 & 1.0 & 0.4 & 0.5 \\
\hline Trees 4 \& 5: & \multicolumn{3}{|c|}{$1.9(150 \mathrm{~cm}) \quad 0.8(77 \mathrm{~cm})$} & \multicolumn{3}{|c|}{$2.4(55 \mathrm{~cm}) \quad 0.6(52 \mathrm{~cm})$} & \multicolumn{3}{|c|}{ - $\quad-$} & \multicolumn{3}{|c|}{$\begin{array}{ll}- & -\end{array}$} & \multicolumn{3}{|c|}{$0.3(68 \mathrm{~cm}) \quad 0.6(77 \mathrm{~cm})$} \\
\hline $\mathrm{Mg}(\mu \mathrm{g} / \mathrm{g})$ & 254 & 1079 & 321 & 95.9 & 104 & 98.2 & 359 & 122 & 86 & 105.6 & 74.2 & 98.2 & 122.4 & 319.8 & 179.3 \\
\hline $\mathrm{Mn}(\mu \mathrm{g} / \mathrm{g})$ & 55.1 & 42.1 & 29.4 & 18.0 & 59.6 & 30.7 & 53.0 & 49.7 & 17.6 & 45.3 & 59.7 & 64.4 & 37.8 & 74.7 & 71.6 \\
\hline $\mathrm{Ni}(\mu \mathrm{g} / \mathrm{g})$ & 3.3 & 6.3 & 4.9 & 1.9 & 0.43 & 2.7 & 0.71 & 1.2 & 0.5 & 0.5 & 0.5 & 0.4 & 0.7 & 5.0 & 1.2 \\
\hline $\mathrm{Pb}(\mu \mathrm{g} / \mathrm{g})$ & 0.48 & 5.3 & 0.17 & 0.53 & 0.07 & 0.67 & $<\mathrm{MDL}$ & $<\mathrm{MDL}$ & $<\mathrm{MDL}$ & $<\mathrm{MDL}$ & $<\mathrm{MDL}$ & $<\mathrm{MDL}$ & $<\mathrm{MDL}$ & $<\mathrm{MDL}$ & $<\mathrm{MDL}$ \\
\hline $\mathrm{Sr}(\mu \mathrm{g} / \mathrm{g})$ & 52.6 & 20.4 & 17.9 & 18.1 & 11.1 & 12.6 & 10.4 & 6.7 & 6.0 & 5.7 & 8.9 & 2.6 & 44.6 & 18.2 & 29.6 \\
\hline Th (ng/g) & $<$ MDL & $<\mathrm{MDL}$ & $<\mathrm{MDL}$ & $<\mathrm{MDL}$ & $<\mathrm{MDL}$ & $<\mathrm{MDL}$ & $<\mathrm{MDL}$ & $<\mathrm{MDL}$ & $<\mathrm{MDL}$ & $<\mathrm{MDL}$ & $<\mathrm{MDL}$ & $<\mathrm{MDL}$ & 9.4 & $<\mathrm{MDL}$ & $<\mathrm{MDL}$ \\
\hline $\mathrm{U}(\mathrm{ng} / \mathrm{g})$ & $<\mathrm{MDL}$ & $<\mathrm{MDL}$ & $<\mathrm{MDL}$ & $<\mathrm{MDL}$ & $<\mathrm{MDL}$ & $<\mathrm{MDL}$ & $<\mathrm{MDL}$ & $<\mathrm{MDL}$ & $<\mathrm{MDL}$ & $<\mathrm{MDL}$ & $<\mathrm{MDL}$ & $<\mathrm{MDL}$ & $<\mathrm{MDL}$ & $<\mathrm{MDL}$ & $<\mathrm{MDL}$ \\
\hline
\end{tabular}

${ }^{*} \mathrm{Hg}$ was determined by DMA in 5 trees per species, except for Pinus Echinata and Pinus Taeda $(n=3)$. Tree circumference (cm) is given in row 3 for trees $1-3$ and in parentheses next to their

$\mathrm{Hg}$ concentration value for trees 4 and 5 . 
Overall, in this communication, we demonstrate that DMAs based on combustion atomic absorption spectrophotometry can be used effectively as an ashing step in the preparation of tree cores for ICP-MS analysis for certain metals, which allows the determination of non-volatile elements in that very same sample. Finally, we note that continued advancements in ICP-MS, including collision/reaction cell- or laser ablation-ICP-MS, may make the technique more suitable for direct multi-element analyses (including mercury) in wood samples.

\section{Materials and Methods}

\subsection{Site Description and Collection of Tree Cores}

Tree cores were collected from five species of tree-eastern red cedar (Juniperus virginiana), loblolly pine (Pinus taeda), shortleaf pine (Pinus echinata), white oak (Quercus alba), and tulip poplar (Liriodendron tulipifera)_from Tallahatchie Experimental Forest (TEF), which is part of the Holly Springs National Forest located in the north central hills of Mississippi (Figure 3). The forest encompasses $629 \mathrm{~km}^{2}$ and was established in 1936 after loblolly pine was planted in the area to convert rapidly eroding abandoned agricultural land to forest. The TEF, located near Oxford, Mississippi, was created in 1950 to study relationships between mixed pine and hardwood forests, flooding, and soil erosion.

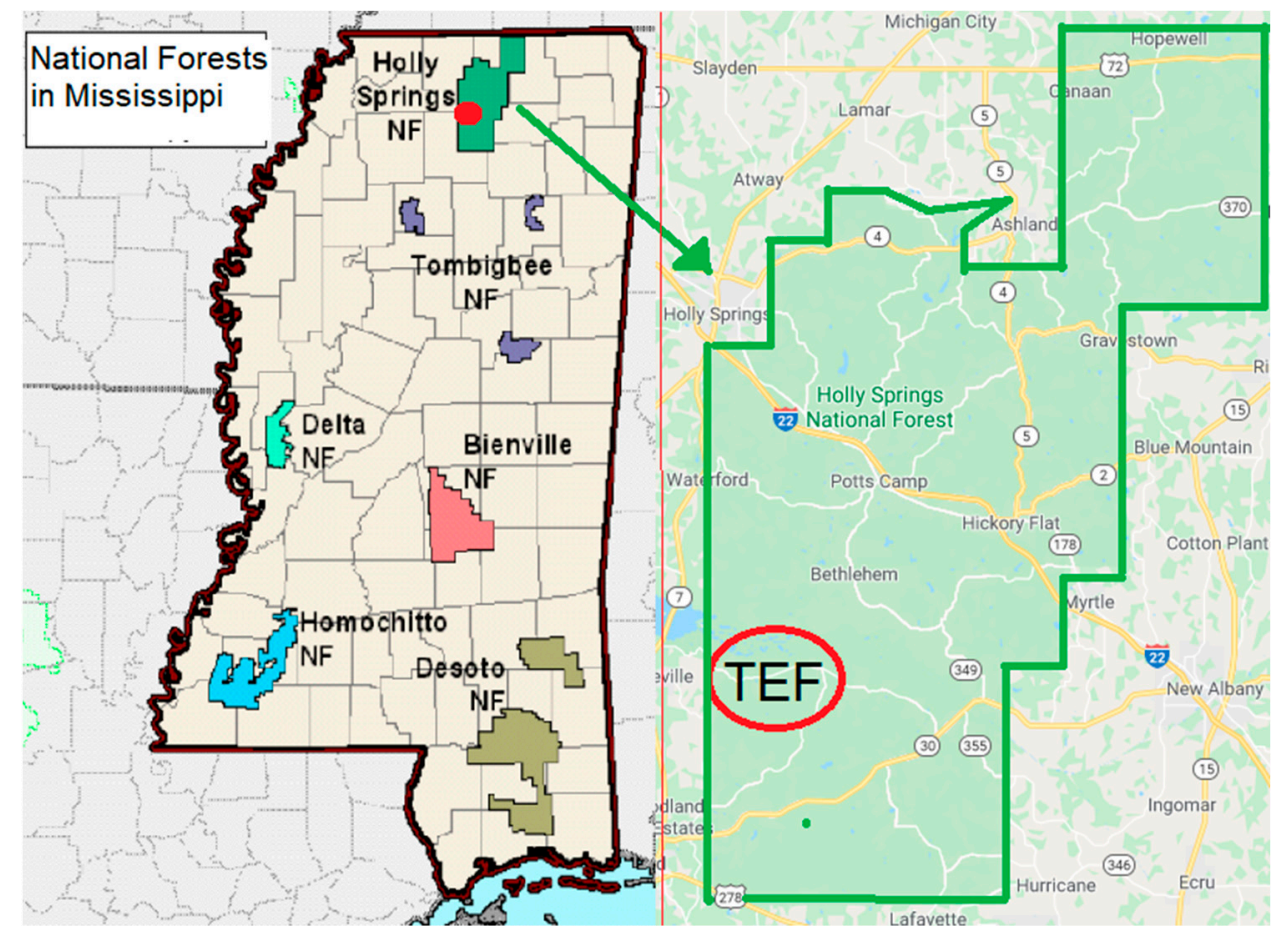

Figure 3. Location of the Tallahatchie Experimental Forest (TEF) in Holly Springs National Forest (NF) in north central Mississippi, USA.

Trees were identified using bark and leaves, and cores were collected at about $1 \mathrm{~m}$ above the ground using a 5.15-mm diameter increment borer made from hardened steel with a PTFE coating (Haglöf, Sweden) or an increment hammer, also made of steel (Figure 4). The extractor is stainless steel. All tools were cleaned and rinsed with deionized water and methanol before sampling. The tools were inspected between uses to make sure no material was transferred between samples. Given the Teflon coating and hardened materials used, we do not expect any impact on metal concentration in the wood. Extracted cores were inserted in an increment core holder, which was placed into Ziploc bags for transport. The cores were air-dried in a laminar flow hood in a clean room for $\sim 1$ week before being stored in a desiccator. This was found to be sufficient for complete dissication before analysis. 


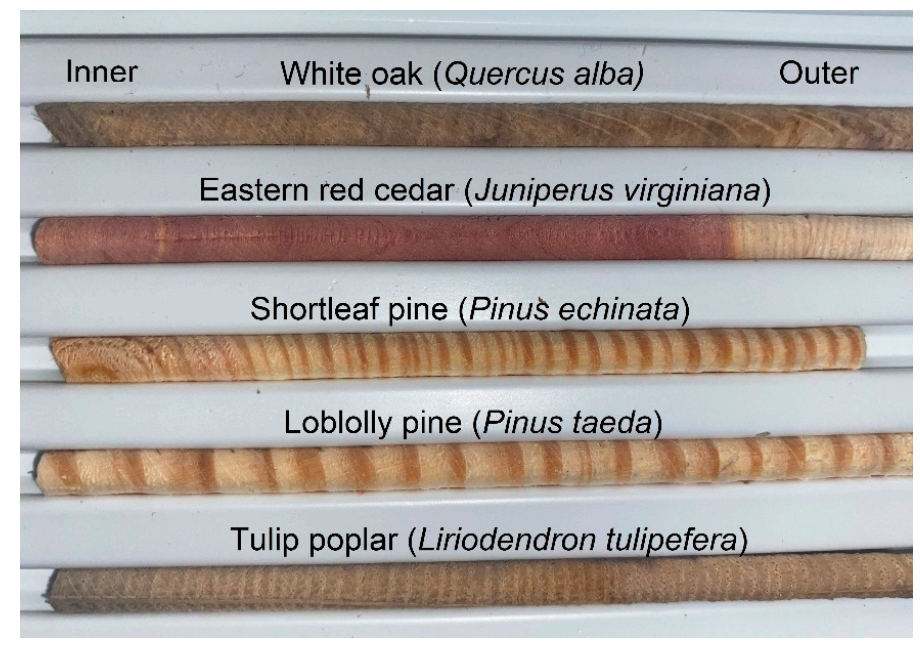

Figure 4. Example of tree cores collected with a 5-mm increment borer.

\subsection{Direct Mercury Analysis}

Total $\mathrm{Hg}$ was determined in $\sim 1 \mathrm{~cm}(\sim 0.1 \mathrm{~g})$ segments of tree core using a DMA-80 (Milestone Inc., Shelton, CT, USA) following EPA Method 7473 with slight modifications. Briefly, the bole wood was weighed into quartz boats and the boats placed in the instrument's autosampler. The boats were sequentially inserted into the unit's combustion tube where the sample was thermally decomposed (combusted) at $650{ }^{\circ} \mathrm{C}$ with air serving as the carrier gas $(200 \mathrm{~mL} / \mathrm{min})$. Instrument parameters are given in Table 4 . The total analysis time was $<5 \mathrm{~min}$ per sample. The instrument was calibrated from 0.05 to $100 \mathrm{ng}$ of $\mathrm{Hg}$ using six standards prepared from $10 \mu \mathrm{g} / \mathrm{mL} \mathrm{Hg}$ standard solution (Spex Certiprep, Metuchen, NJ, USA). The system was checked for accuracy at the beginning and end of each run using SRM1633C (Coal Fly Ash). Recoveries were between $90 \%$ and $115 \%$. Ash residue was carefully weighed into micro-sampling inserts for microwave digestion.

\subsection{Microwave-Assisted Acid Digestion of Tree Core Ash}

A general scheme showing the analytical process is given in the graphical abstract. The ash remaining after DMA analysis of the dried tree core segments $(\sim 10 \mathrm{mg})$ was digested with $1.5 \mathrm{~mL}$ of $\mathrm{HNO}_{3}$ and $50 \mu \mathrm{L}$ of $\mathrm{HF}$ (both trace metal grade, Fisher Chemical, Pittsburgh, PA, USA) in acid-cleaned $6 \mathrm{~mL}$ TFM micro sampling inserts using a $1200 \mathrm{~W}$ Ethos microwave digestion system (Milestone Inc., Shelton, CT, USA). The temperature program consisted of a $15 \mathrm{~min}$ ramp to $200{ }^{\circ} \mathrm{C}$ and a $20 \mathrm{~min}$ hold at that temperature. The resulting digest was transferred to polyethylene tubes and diluted to $50 \mathrm{~mL}$ with ultrapure water (deionized and $0.2 \mu \mathrm{m}$-filtered with a Milli-Q system; Millipore, Burlington, MA, USA). An additional 1:5 dilution was carried out in $2 \% \mathrm{HNO}_{3}$. Sc, Rh, and Bi were used as internal standards at a final concentration of $1 \mathrm{ng} / \mathrm{mL}$. Note, further dilution may be needed for certain elements like $\mathrm{Mg}$ and Ba depending on instrument sensitivity and concentrations in the samples. Reagent blanks were run with every set of digestions. Two reference materials were used to validate the new method. AR1946 is a wood fuel biomass CRM (Alpha Resources LLC, Stevensville, MI, USA) and SRM1633C is a coal fly ash SRM (NIST; Gaithersburg, MD, USA). The digested solutions were analyzed using a sector field-ICP-MS.

\subsection{Determination of Metals in Ash from the DMA by ICP-MS}

Concentrations of 20 elements were determined by sector field ICP-MS using a Thermo Fisher Element-XR. The instrument features resolving power $(\mathrm{m} / \Delta \mathrm{m})$ settings of low $(\sim 300)$ and medium $(\sim 3000)$ to remove certain isobaric interferences. We measured $\mathrm{Be}, \mathrm{Rb}, \mathrm{Sr}, \mathrm{Ag}, \mathrm{Cd}, \mathrm{Cs}, \mathrm{Ba}, \mathrm{Tl}, \mathrm{Pb}, \mathrm{Th}$ and $\mathrm{U}$ in low resolution and $\mathrm{Mg}, \mathrm{V}, \mathrm{Cr}, \mathrm{Mn}, \mathrm{Fe}, \mathrm{Co}, \mathrm{Ni}, \mathrm{Cu}$, and $\mathrm{Ga}$ in medium resolution. Data acquisition parameters are given Table 4 . Samples were introduced using a PFA concentric nebulizer 
and a PFA cyclonic chamber (Elemental Scientific, USA). The system was optimized for sensitivity and stability, yielding $~ 0.8$ million counts-per-second for $1 \mathrm{ng} / \mathrm{g}$ of ${ }^{115} \mathrm{In}$ in low resolution mode with $<3.5 \%$ relative standard deviation (RSD). The mass window was set to $20 \%$ with 50 points per peak for low resolution mode and to $125 \%$ with 20 points per peak for medium resolution mode. Elements were quantified using external calibration which consisted of a blank, 0.05, 0.1, 0.2, 0.5, 1, $5 \mathrm{ng} / \mathrm{g}$ standards from a multi-element solution (Spex CertiPrep, Metuchen, NJ, USA). The calibration curve correlation coefficient $\left(\mathrm{r}^{2}\right)$ values were $>0.994$ for each element.

To back-calculate the concentration of the metals in the wood, the solution concentration was multiplied by a dilution factor consisting of the mass of the solution (after digestion and dilution to $50 \mathrm{~mL}$ mark) divided by the original weight of sample multiplied by 5 to account for the 1:5 dilution of the digest prior to analysis. Concentrations reported herein are based on dry-weight.

Table 4. Direct mercury analyzer (DMA) and ICP-MS instrumental settings.

\begin{tabular}{lc}
\hline & DMA \\
\hline Gas flow & $200 \mathrm{~mL} / \mathrm{min}$ \\
Drying & $200{ }^{\circ} \mathrm{C}$ for $60 \mathrm{~s}$ \\
Decomposition & $650{ }^{\circ} \mathrm{C}$ for $180 \mathrm{~s}$ \\
Purge & $60 \mathrm{~s}$ \\
Amalgamator heat & $900{ }^{\circ} \mathrm{C}$ for $12 \mathrm{~s}$ \\
Record & $60 \mathrm{~s}$ \\
\hline & Plasma Parameters \\
\hline Cool gas flow & $14 \mathrm{~L} / \mathrm{min}$ \\
Auxiliary gas flow & $0.9 \mathrm{~L} / \mathrm{min}$ \\
Sample gas flow & $1.1 \mathrm{~L} / \mathrm{min}$ \\
RF power & $1280 \mathrm{~W}$ \\
\hline & $\mathrm{MS} \mathrm{Data}$ Acquisition \\
\hline & ${ }^{9} \mathrm{Be},{ }^{85} \mathrm{Rb},{ }^{88} \mathrm{Sr}, 107 \mathrm{Ag},{ }^{111} \mathrm{Cd},{ }^{133} \mathrm{Cs},{ }^{137} \mathrm{Ba},{ }^{205} \mathrm{Tl}$, \\
Isotopes in LR & $208 \mathrm{~Pb},{ }^{232} \mathrm{Th},{ }^{238} \mathrm{U}$ \\
Isotopes in MR & $24 \mathrm{Mg},{ }^{51} \mathrm{~V},{ }^{52} \mathrm{Cr},{ }^{55} \mathrm{Mn},{ }^{56} \mathrm{Fe},{ }^{59} \mathrm{Co},{ }^{60} \mathrm{Ni},{ }^{63} \mathrm{Cu},{ }^{69} \mathrm{Ga}$ \\
Integration time & $10 \mathrm{~ms}(\mathrm{LR}) ; 50 \mathrm{~ms}(\mathrm{MR})$ \\
Mass window & $20 \%$ for LR; $125 \%$ for MR \\
Points per peak & $50(\mathrm{LR}) ; 20(\mathrm{MR})$ \\
Runs/passes & $3 / 3(\mathrm{E}-\mathrm{scan})$ \\
\hline
\end{tabular}

LR = Low Resolution; MR = Medium Resolution.

Author Contributions: B.J. led the sampling and measurement campaign; B.J. and J.V.C. analyzed and interpreted the data and authored the manuscript; J.V.C. conceptualized, supervised, and administered the project. All authors have read and agreed to the published version of the manuscript.

Funding: This research received no external funding.

Acknowledgments: We are grateful to the US Forest Service personnel for support and guidance, especially Lorenzo Walton and James Schiller. Steve Brewer at the University of Mississippi Biology Department helped with identification of tree species.

Conflicts of Interest: The authors declare no conflict of interest.

\section{References}

1. Watmough, S.A.; Hutchinson, T.C. Analysis of tree rings using inductively coupled plasma mass spectrometry to record fluctuations in a metal pollution episode. Environ. Pollut. 1996, 93, 93-102. [CrossRef]

2. Bindler, R.; Renberg, I.; Klaminder, J.; Emteryd, O. Tree rings as Pb pollution archives? A comparison of $206 \mathrm{~Pb} / 207 \mathrm{~Pb}$ isotope ratios in pine and other environmental media. Sci. Total Environ. 2004, 319, 173-183. [CrossRef]

3. Cheng, Z.; Buckley, B.M.; Katz, B.; Wright, W.; Bailey, R.; Smith, K.T.; Li, J.; Curtis, A.; van Geen, A. Arsenic in tree rings at a highly contaminated site. Sci. Total Environ. 2007, 376, 324-334. [CrossRef] [PubMed] 
4. Hojdová, M.; Navrátil, T.; Rohovec, J.; Žák, K.; Vaněk, A.; Chrastný, V.; Bače, R.; Svoboda, M. Changes in Mercury Deposition in a Mining and Smelting Region as Recorded in Tree Rings. Water Air Soil Pollut. 2011, 216, 73-82. [CrossRef]

5. Cutter, B.E.; Guyette, R.P. Anatomical, Chemical, and Ecological Factors Affecting Tree Species Choice in Dendrochemistry Studies. J. Environ. Qual. 1993, 22, 611-619. [CrossRef]

6. McCarroll, D.; Loader, N.J. Stable isotopes in tree rings. Quat. Sci. Rev. 2004, 23, 771-801. [CrossRef]

7. Monticelli, D.; Di Iorio, A.; Ciceri, E.; Castelletti, A.; Dossi, C. Tree ring microanalysis by LA-ICP-MS for environmental monitoring: Validation or refutation? Two case histories. Microchim. Acta 2009, 164, 139-148. [CrossRef]

8. Padilla, K.L.; Anderson, K.A. Trace element concentration in tree-rings biomonitoring centuries of environmental change. Chemosphere 2002, 49, 575-585. [CrossRef]

9. Schroeder, W.H.; Munthe, J. Atmospheric mercury-An overview. Atmos. Environ. 1998, 32, 809-822. [CrossRef]

10. Yang, Y.; Yanai, R.D.; Driscoll, C.T.; Montesdeoca, M.; Smith, K.T. Concentrations and content of mercury in bark, wood, and leaves in hardwoods and conifers in four forested sites in the northeastern USA. PLoS ONE 2018, 13, e0196293. [CrossRef]

11. Gustin, M.S.; Evers, D.C.; Bank, M.S.; Hammerschmidt, C.R.; Pierce, A.; Basu, N.; Blum, J.; Bustamante, P.; Chen, C.; Driscoll, C.T.; et al. Importance of Integration and Implementation of Emerging and Future Mercury Research into the Minamata Convention. Environ. Sci. Technol. 2016, 50, 2767-2770. [CrossRef] [PubMed]

12. Becnel, J.; Falgeust, C.; Cavalier, T.; Gauthreaux, K.; Landry, F.; Blanchard, M.; Beck, M.J.; Beck, J.N. Correlation of mercury concentrations in tree core and lichen samples in southeastern Louisiana. Microchem. J. 2004, 78, 205-210. [CrossRef]

13. Siwik, E.I.H.; Campbell, L.M.; Mierle, G. Distribution and trends of mercury in deciduous tree cores. Environ. Pollut. 2010, 158, 2067-2073. [CrossRef] [PubMed]

14. Yang, Y.; Yanai, R.D.; Montesdeoca, M.; Driscoll, C.T. Measuring mercury in wood: Challenging but important. Int. J. Environ. Anal. Chem. 2017, 97, 456-467. [CrossRef]

15. Obrist, D.; Johnson, D.W.; Edmonds, R.L. Effects of vegetation type on mercury concentrations and pools in two adjacent coniferous and deciduous forests. J. Plant Nutr. Soil Sci. 2012, 175, 68-77. [CrossRef]

16. Navrátil, T.; Šimeček, M.; Shanley, J.B.; Rohovec, J.; Hojdová, M.; Houška, J. The history of mercury pollution near the Spolana chlor-alkali plant (Neratovice, Czech Republic) as recorded by Scots pine tree rings and other bioindicators. Sci. Total Environ. 2017, 586, 1182-1192. [CrossRef]

17. Wright, G.; Woodward, C.; Peri, L.; Weisberg, P.J.; Gustin, M.S. Application of tree rings [dendrochemistry] for detecting historical trends in air $\mathrm{Hg}$ concentrations across multiple scales. Biogeochemistry 2014, 120, 149-162. [CrossRef]

18. Peckham, M.A.; Gustin, M.S.; Weisber, P.J. Assessment of the Suitability of Tree Rings as Archives of Global and Regional Atmospheric Mercury Pollution. Environ. Sci. Technol. 2019, 53, 3663-3671. [CrossRef]

19. Schneider, L.; Allen, K.; Walker, M.; Morgan, C. HaberleUsing Tree Rings to Track Atmospheric Mercury Pollution in Australia: The Legacy of Mining in Tasmania. Environ. Sci. Technol. 2019, 53, 5697-5706. [CrossRef]

20. Cocozza, C.; Ravera, S.; Cherubini, P.; Lombardi, F.; Marchetti, M.; Tognetti, R. Integrated biomonitoring of airborne pollutants over space and time using tree rings, bark, leaves and epiphytic lichens. Urban For. Urban Green. 2016, 17, 177-191. [CrossRef]

21. Madejón, P.; Marañón, T.; Murillo, J.M.; Robinson, B. White poplar (Populus alba) as a biomonitor of trace elements in contaminated riparian forests. Environ. Pollut. 2004, 132, 145-155. [CrossRef] [PubMed]

Sample Availability: Not available.

(C) 2020 by the authors. Licensee MDPI, Basel, Switzerland. This article is an open access article distributed under the terms and conditions of the Creative Commons Attribution (CC BY) license (http://creativecommons.org/licenses/by/4.0/). 